\title{
Fé e mídia: um exame do discurso testemunhal da igreja mundial do poder de Deus
}

Jarbas Vargas NASCIMENTO

Leonardo Teixeira Ribeiro de Freitas VILHAGRA

\section{Considerações iniciais}

Supondo que "todo homem é um ser religioso que tem dentro de si uma força que o impele para Deus" (JUNG, 1875-1961) e associando-o à sua dimensão social, que o leva a utilizar a linguagem, para se relacionar com a divindade e ressignificar o mundo discursivamente, abre-se à Linguística contemporânea, particularmente para a Análise do Discurso, uma possibilidade interdisciplinar de investigar uma das formas de interação social, que o ser humano estabelece no espaço íntimo do ritual religioso que, hoje, quase sempre, é reproduzido, multiplicado e divulgado em suporte digital. 
Nos últimos anos, com o avanço das teorias de informação e comunicação, que interferem diretamente na produção discursiva em nossa sociedade, estudiosos de determinadas teorias linguísticas e outros de diferentes áreas do conhecimento tem se debruçado sobre questões que ampliam a compreensão da linguagem, da Religião, da mídia e do homem enquanto sujeito-no-mundo, impulsionados pela imposição de processos de modernização (HASMMAN, 1986; STOLOW, 2012; MARANHÃO FILHO, 2013; BARROSO, 2014). Por isso, mais do que estudar aqueles campos discursivos, vemo-nos reconstruindo conhecimento e ampliando os espaços em que, particularmente, a linguagem, a Religião e a mídia interagem para reconfigurarem a prática discursiva religiosa.

Aliás, é pertinente observar o uso do site pela IMPD. Feitosa (2013, p. 212-213), refletindo sobre a Religião na mídia, enfatiza:

A cada dia percebe-se o fortalecimento da presença da Igreja nas mídias eletrônicas. Programas radiofônicos com orações, rezas, aconselhamentos; cultos televisivos que são verdadeiros shows; novelas que contam a história de José, Sansão e Dalila e tantos outros personagens bíblicos; filmes em cinemas que retratam a morte de Cristo, e até a vida de José e Maria como atletas; sites religiosos onde é possível acender vela virtual, rezar terço on-line, fazer macumba, confessar-se, assistir a missas e cultos, e, ultimamente, seguir o papa no twitter. A Igreja, efetivamente, incorporou a mídia utilizando o poder midiático para exercer o seu poder simbólico. 
Na verdade, neste capítulo, nosso objetivo central é examinar o discurso religioso testemunhal enunciado em voz alta por um fiel em ritual da/na Igreja Mundial do Poder de Deus (IMPD) e que, posteriormente, foi retextualizado e disponibilizado no site desta Instituição. Não nos interessa analisar o discurso testemunhal no ritual, no ambiente da Igreja, pois isso implicaria refletir sobre a sua singularidade, seus elementos simbólicos e sua dimensão pessoal e transcendental, onde o ser humano se inscreve socialmente em uma memória atemporal. Nossa investigação aqui se delimita ao discurso testemunhal postado no site, porque, neste espaço digital, "a marca principal está na busca dispersa, alinear, fragmentada, mas certamente uma busca individualizada da mensagem e da informação" (SANTAELLA, 2003, p. 27). No final das contas, a imposição de tecnologias digitais, em nosso caso, a produtividade do site, autoriza o ato de linguagem e desvela-nos uma espetacularização de uma manifestação religiosa e um evidente investimento na propagação da fé, imprimindo novas configurações comportamentais para a Religião institucionalizada.

Chama-nos a atenção o fato de podermos argumentar, com razão, que a Linguística pode ocupar-se da Religião, ao tratá-la como produtora de discurso (ORLANDI, 2001) e, nesta dialogicidade, aproximar-se dela, tornando-se áreas convergentes. Já passara o tempo em que os textos religiosos eram apreendidos e interpretados unicamente sob a ótica da Hermenêutica e/ou da Exegese Bíblica. O próprio Gadamer (2002), um dos principais autores de Hermenêutica do século XX, admite a necessidade de adoção de mais de uma metodologia, para se alcançar o verdadeiro sentido de um texto. Assim, na esteira deste argumento, pressupomos que os estudos linguísticos possam ampliar o processo de inteligibilidade de diferentes textos, principalmente, os da Religião na mídia. 
Para tanto, fundamentamo-nos no quadro teórico-metodológico da Análise do Discurso de linha francesa (AD), na abordagem de Maingueneau, cujas pesquisas têm trazido contribuições imprescindíveis para o desenvolvimento da Linguística e da Comunicação. A perspectiva enunciativo-discursiva proposta por Maingueneau em seus estudos motiva-nos a considerar as condições sócio-históricas de produção, ou seja, a pertinência de fatores internos e externos ao discurso testemunhal da IMPD, a responsabilidade do sujeito na enunciação, bem como o papel que as formações discursivas neopentecostais conferem ao discurso e que representam a conjuntura sócio-histórica desta instituição. Ao adotarmos esta abordagem, estamos confirmando a eficiência e a eficácia de a AD alcançar resultados analítico-críticos positivos nos campos da linguagem e da religiosidade e, consequentemente, na ordem do ser, ou seja, na comunhão humana com o transcendente. Desse modo, faz-se necessário aprimorarmos nossos constructos teórico-metodológicos, abandonarmos as perspectivas interpretativas canônicas e conservadoras e enfrentarmos novos desafios investigativos, que a atualidade nos impõe e que visam a tornar menos reducionistas as questões de nossa vida particular e coletiva.

Para dar conta do tema que propomos e, dado o caráter interdisciplinar da $\mathrm{AD}$, adotamos como dispositivos complementares essenciais, para a análise que empreenderemos, as reflexões de Hervieu-Léger (2008), da Sociologia da Religião, e Hassman (1986), Maranhão Filho (2013) e Feitosa, (2013), da Comunicação Midiática que, em aliança com Maingueneau, vão nos possibilitar colocar em foco o discurso testemunhal e a tensão que recai sobre o enunciador religioso, ao ser apreendido por um posicionamento no ritual e outro no site. Nesse espaço digital, os atos de linguagem do enunciador da IMPD desestabilizam, deslocam e reconfiguram os efeitos de sentido religiosos. Diante da percepção que ex- 
perimentamos, ao identificarmos, na cenografia midiatizada, um sujeito frente ao transcendente, justificamos a escolha do corpus selecionado, destacando tal testemunho como um discurso institucional que legitima dizeres que fidelizam antigos e atraem novos crentes.

Dentre as várias práticas religiosas ressignificadas pelos neopentecostais, encontramos o testemunho. Tradicionalmente, ele estava ligado a um relato oral de transmissão da palavra de Deus pelo mundo, a partir de uma experiência individual, contemplada por um evento sobrenatural. Contudo, no presente, o testemunho, no contexto das igrejas neopentecostais é outro. Eles são produzidos, com o intuito de não só expor as conquistas materiais dos fieis, mas também como divulgação da instituição, como evidencia Barbosa (2011, p. 15).

É este o discurso frequente dos pastores. Durante as visitas de campo, pude perceber o quão esta ideia de eficácia institucional é divulgada, principalmente através dos testemunhos dos crentes que receberam a cura. Eles são usados para a veiculação de propagandas na TV e na internet.

Em termos pragmáticos, podemos dizer que a Religião, muitas vezes, tem um papel significativo para o ser humano, até essencial à sua vida. Independente de seus posicionamentos, a Religião sempre pretendeu dar respostas a questões existenciais incompreensíveis aos olhos humanos. Por isso, seria um absurdo depreciarmos aqueles que buscam prosperidade, conforto material, paz e segurança na Religião e reprovarmos aquelas instituições religiosas, que se voltam para a sensibilização de convicções da subjetividade do homem. 


\section{As condições sócio-históricas de produção do dis- curso testemunhal da Igreja Mundial do Poder de Deus}

O Neopentecostalismo constitui um movimento religioso surgido do pentecostalismo e desenvolvido no contexto da secularização e do crescimento urbano (FRESTON, 1994). Esse movimento se alicerça sobre a Teologia da Prosperidade e toma-a como fundamento doutrinário essencial, pois, para o Neopentecostalismo, todo crente deve ser próspero durante sua vida na terra. Nesta lógica, para os adeptos deste posicionamento, quanto mais próspero na terra, mas próspero no céu. Reforçando este princípio, para Nunes (2006, p. 128),

[...] estabelece-se uma espécie de "contrato" com Deus, onde "quanto mais se dá para Deus, mais se recebe." A prosperidade está aberta a todos, mas é preciso que se dê a maior quantia de dinheiro para a igreja, pois só assim o fiel conseguirá a satisfação de seus problemas terrenos. A prosperidade econômica é vista como um sinal da graça divina. O dinheiro é adorado e tudo o que dele se origina não é mais visto como "pecado" ou "coisa do diabo".

Pesquisas revelam que, quando descrevem a experiência neopentecostal, seus estudiosos mostram sua influência sobre a fundação e a expansão de inúmeras igrejas, dentre elas, a IMPD e os fatos que ocasionaram nela cisões e desdobramentos. O que ressaltamos sobre a expansão do Neopentecostalismo é a sua visibilidade, em especial, por sua propagação na mídia e o destaque de seus adeptos na política. Não há dúvidas de que o fato de assumirem aspectos litúrgicos do catolicismo forçou os crentes neopentecostais a mul- 
tiplicarem sua doutrina e adequá-la mais diretamente aos anseios de suas comunidades. É com o Neopentecostalismo e sua Teologia da Prosperidade que a doutrina cristã se ressignifica, sobretudo, ajustando-se à modernidade, onde o individualismo, o racionalismo e os valores materiais são privilegiados.

Neste sentido, o fato de a "AD apreender o discurso enquanto articulação entre texto e lugares sociais" (MAINGUENEAU, 2013, p. 3), faz que ela se mostre plenamente produtiva na análise de discursos da religiosidade, na medida em que pode incidir sobre questões enunciativas e outras psicossociológicas que mobilizam, em nosso caso, o sujeito sobredeterminado pelo posicionamento neopentecostal e pela IMPD que o valida. Dizer que o discurso testemunhal é o religioso é considerar que a IMPD pode assumir na sociedade o espaço da Religião e que seu fundador, o apóstolo Waldemiro Santiago, investido do estatuto de autoridade, segundo a função que ocupa, pode decidir sobre os aparelhos ideológicos da religiosidade (ALTHUSSER, s/d).

Quanto às normas de organização discursiva, podemos dizer que a cenografia do discurso testemunhal desfruta de relativa autonomia para, por meio de atos de linguagem, materializar uma espiritualidade existencial e corporal de forma que a fé se torne visível aos olhos dos que creem. Para compreendermos melhor a produção de discursos religiosos nas instituições neopentecostais, é necessário considerarmos o argumento de Mariz (2001, p. 39), quando esclarece que

[...] os cultos/pregações pentecostais, as orações carismáticas e também seus discursos se direcionam para aspectos que mais afligem as pessoas: problemas familiares (brigas entre pais e filhos, casamento em crise, adultério, solidão), de saúde (especialmente drogas e alcoolismo) e sobrevivência material (dinheiro, emprego). 
Sem entrar em pormenores da Sociologia da Religião, é fundamental trazer aqui o pensamento de Hervieu-Léger (2008) com uma contribuição teórica para a análise do discurso da IMPD. Dentre as reflexões da autora, ressaltamos seu postulado sobre a racionalização humana e da relação entre modernidade e religiosidade. Para Hervieu-Léger, hoje, para se manter em sociedade, não há necessidade de recorrer ao transcendente ou buscar explicação fora do alcance da mente humana. A autora utiliza a terminologia "linha crente" e sobre esse conceito, Camurça (2003, p. 251) nos diz que

[...] a crença religiosa é uma crença na continuidade da "linha crente". É o processo de conservação e reprodução desta "linha" por meio da memória religiosa que garante a permanência da religião, dando sentido ao presente e assegurando o futuro dentro do percurso da "linha", cujo ponto de origem é o passado sempre perenizado.

Assim, a "linha crente" é constantemente revisitada, com a finalidade de fundamentar as ações das religiões tradicionais no presente. Contudo, as sociedades de hoje solaparam essa memória religiosa,

Pela afirmação da racionalidade que questionam as estruturas de plausibilidade do passado religioso fundante como referência; [...] pela superabundância de informações veiculadas pelos meios de comunicação, que resulta em uma perda da profundidade e do continuum da memória coletiva em prol de uma presentificação dos acontecimentos (CARMUÇA, 2003, p. 253). 
Para Hervieu-Léger (2008, p. 33), o traço determinante da modernidade "[...] é aquele que marca a cisão com o mundo da tradição: a afirmação segundo a qual o homem é o legislador de sua própria vida”. Neste cenário, a importância da memória religiosa, ou seja, o seu caráter coletivo perde força, ao passo que o caráter individual se acentua. A partir desse cenário, a autora confirma que, atualmente, nasce um novo tipo de Religião, as chamadas pós-tradicionais, cujas características acentuam, por um lado, a adaptação das crenças ao indivíduo, como ocorrem nos testemunhos, e, por outro, o enfraquecimento de pertença dos fieis a uma única instituição e a crescente mobilidade religiosa.

Em contrapartida, sobre a adaptação das crenças ao indivíduo, Mariano (2010, p. 26) nos mostra que o Neopentecostalismo se afasta das tradições cristãs, pois ele almeja:

(1) pregar e difundir a Teologia da Prosperidade, defensora do polêmico e desvirtuado adágio franciscano "é dando que se recebe" e da crença nada franciscana de que o cristão está destinado a ser próspero materialmente, saudável, feliz e vitorioso em todos os seus empreendimentos terrenos; (2) enfatizar a guerra espiritual contra o Diabo, seu séquito de anjos decaídos e seus representantes na terra, identificados com as outras religiões e, sobretudo com os cultos afro-brasileiros; (3) não adotar os tradicionais e estereotipados usos e costumes de santidade, que até há pouco figuravam como símbolos de conversão e pertencimento ao pentecostalismo.

Além disso, acerca do enfraquecimento de pertença dos fieis frente à instituição e da crescente mobilidade religiosa, Mariano (2013, p. 126) evidencia, a partir do senso do IBGE de 2010, dados sobre a situação da religiosidade brasileira. A inusitada queda numérica de sete igrejas evangélicas, com efeito, confere maior importância à discussão sobre o repentino e extraordinário inchaço da categoria evangélica não determinada. 
É em uma conjuntura de dissidências, de conversões e fluidez religiosa que a IMPD se encontra. Fundada, em 1998, na cidade de Sorocaba, sua criação acontece de divergência com Edir Macedo, bispo da Igreja Universal do Reino de Deus (IURD). Após um desentendimento, Waldemiro Santiago, que estava investido de altos cargos e significativo prestígio na IURD, abandona-a, a fim de criar sua própria Igreja, a IMPD, com templos edificados em todas as capitais do Brasil, além de outros na América, Ásia e África, sendo, por conseguinte, uma produtora de discurso.

\section{As categorias}

Estamos partindo do pressuposto de que fazer pesquisa é uma prática social e que o arcabouço-teórico metodológico da $\mathrm{AD}$, em quanto dispositivo analítico, pode contribuir para o conhecimento do discurso testemunhal e, por ela, ampliar o entendimento do ser humano materializado em seu dizer. Nossa opção pela AD se justifica, também, pelo tratamento que esta disciplina dá ao discurso e a forma como busca sua inteligibilidade pela negociação de efeitos de sentido e legitimação de conhecimentos, embora Maingueneau postule que o analista do discurso não deve examinar o discurso em si, "mas um espaço de trocas entre vários discursos convenientemente escolhidos" (MAINGUENEAU, 2008b, p. 20).

Faz-se necessário esclarecer que, para Maingueneau, esse espaço de troca é o interdiscurso e deve ser colocado em primeiro plano no processo analítico de práticas discursivas. Para o autor, o interdiscurso se define pela tríade: universo discursivo, campo discursivo e espaço discursivo. O universo discursivo corresponde ao espaço de existência de todos os tipos de discurso; o campo discursivo corresponde às funções sociais que os discursos assumem na relação entre eles, e o espaço discursivo corresponde a um con- 
junto de formações discursivas, que o analista julga indispensáveis à sua pesquisa.

A adoção da categoria de interdiscurso possibilita ao analista visualizar uma tensão entre diferentes formações discursivas que entram em concorrência no funcionamento do discurso, como redes de interação semântica, advindas de diversos eventos sociodiscursivos. Em nosso caso, podemos dizer que a cura, a família, o financeiro e a salvação, mesmo integrando diferentes posições enunciativas e diferentes campos discursivos - saúde, social, econômico e teológico - garantem uma identidade religiosa ao discurso da IMPD. Por isso, podemos afirmar com Maingueneau (2008b, p. 103):

Quando se considera o espaço discursivo como rede de interação semântica, ele define um processo de interincompreensão generalizada, a própria condição de possibilidade das diversas posições enunciativas.

Na visão de Maingueneau, uma formação discursiva (FD) interpreta outra, tendo como referência o seu próprio termo e categoria. Logo, o efeito de sentido será plástico, formado neste espaço de diferentes posições enunciativas. Mas, como bem lembra Maingueneau (1997), essa tradução não é de “[...] uma língua natural para outra, mas de uma formação discursiva à outra, isto é, entre zonas da mesma língua” (MAINGUENEAU, 1997, p. 120).

Ao empregarmos as categorias de interdiscurso (Maingueneau, 2008b), da citação (2002, 2008a, 2014) da aforização (Maingueneau 2008a, 2011 e 2014), queremos agregar a essas noções são dispositivos, que nos ajudarão a negociar efeitos de sentido e a preservar a identidade institucional da IMPD, no espaço discursi- 
vo. A negociação de efeitos de sentido é uma atividade interativa, sócio-historicamente constituída, de forma que deve nos levar a perceber a maneira como, na IMPD, a fé se articula com questões da vida cotidiana de homens e mulheres no processo de engajamento religioso.

Vamos agora centrar nossa reflexão na categoria frases sem texto e dela destacarmos a aforização e a sobreasseveração; antes, é necessário evidenciar a emergência desses conceitos atualmente. Maingueneau (2011) chama nossa atenção, para não confundirmos aforização com sobreasseveração. Para o autor, a sobreasseveração não é uma citação, mas um fragmento textual que se destaca de um texto-fonte. $\mathrm{O}$ fato de sua destacabilidade pode ser transformado, inclusive, em um título. Nesta perspectiva, de um lado, a sobreasseveração põe em realce uma sequência sobre um fundo textual. A aforização, de outro lado, contextualiza um enunciado desprovido de contexto (Maingueneau, 2011), ou seja, ela se caracteriza por fragmentos de textos destacados dentro de um gênero de discurso, mas não fica presa a ele, podendo transitar para outros gêneros. Não há posições correlativas, mas uma instância que fala a uma espécie de

'auditório universal' (Perelman), que não se reduz a um destinatário localmente especificado: a aforização institui uma cena de fala onde não há interação entre dois protagonistas colocados num mesmo plano. (MAINGUENEAU, 2010, p. 13).

Exemplos de aforização são "provérbios, emblemas, slogans etc. ou de frases que tenham sido destacadas de textos diversos" (MAINGUENEAU, 2011, p. 17). Como há enunciados aforizantes, há, também, os textualizantes, ou seja, enunciados destacáveis, 
os quais são candidatos a uma "destextualização" (MAINGUENE$\mathrm{AU}, 2011)$. Eles permanecem dentro do gênero de discurso, em posição de destaque, ampliando certas sequências dele. Tomando como base enunciados textualizantes, Maingueneau desenvolve o conceito de sobreasseveração. Para o autor, a sobreasseveração caracteriza um enunciado:

- relativamente breve, de estrutura pregnante no plano do significado e/ou do significante;

- em posição relevante no texto ou em uma passagem do texto, de modo a the atribuir o estatuto de um condensado semântico, o produto de uma espécie de sedimentação da realização do discurso;

- tal que sua temática deve estar em relação com o intuito do gênero de discurso, do texto em questão: trata-se de uma tomada de posição no interior de um conflito de valores;

- implica um tipo de 'amplificação' da figura do enunciador, manifestada por um ethos apropriado. (MAINGUENEAU, 2008a, p. 82).

Além disso, a sobreasseveração possui recursos de diversos níveis para se manifestar, como

[...] marcadores de ordem aspectual (generalização), marcadores tipográficos (posição de destaque em uma unidade textual), prosódicos (insistência), sintáticos (especialmente o recurso a construções simétricas), semân- 
ticos (utilização de tropos: metáforas, paradoxos etc.), lexicais (utilização de conectores de reformulação), poéticos (rimas) etc. (MAINGUENEAU, 2011, p. 16).

Desta forma, a sobreasseveração projeta o texto fonte, de modo a evidenciar que o enunciador não apenas diz, "[...] mas que mostra que diz o que diz, e presume-se que o que ele diz condensa uma mensagem forte, induz a uma tomada de posição exemplar" (MAINGUENEAU, 2008a, p. 91).

Maingueneau (2008a), postula, ainda, que os discursos se materializam nos mais variados gêneros; no entanto, hoje, a circulação deles está cada dia mais coexistindo como partes deles, ou seja, da mesma forma que um gênero de discurso religioso pode circular, um enunciado dele também pode circular por meio da destacabilidade, que se caracteriza por sentenças "curtas, bem estruturadas, de modo a impressionar, a serem facilmente memorizáveis e reutilizáveis" (MAINGUENEAU, 2008a, p. 77). Além disso, ela pode permanecer dentro do gênero de origem, como também, investida de certa autonomia, difundir-se em outros. Esse fenômeno pode ocorrer de duas formas, conforme a ilustração a seguir evidencia

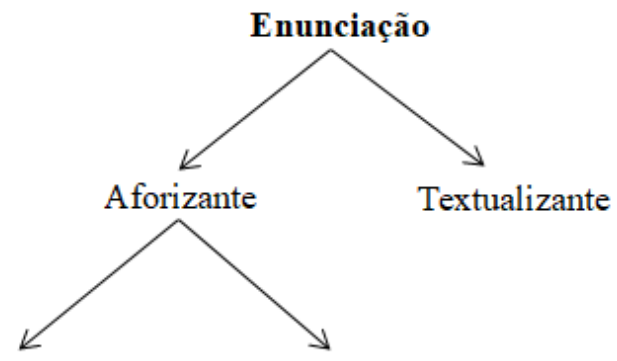

Destacada por natureza Destacada de um texto

Figura 1. enunciados aforizantes e textualizantes Fonte: Maingueneau, 2011, p. 18. 


\section{Um exemplo de análise}

Conforme já explicitamos, selecionamos para análise um discurso testemunhal postado nos site da IMPD, no endereço eletrônico www.impd.org.br.

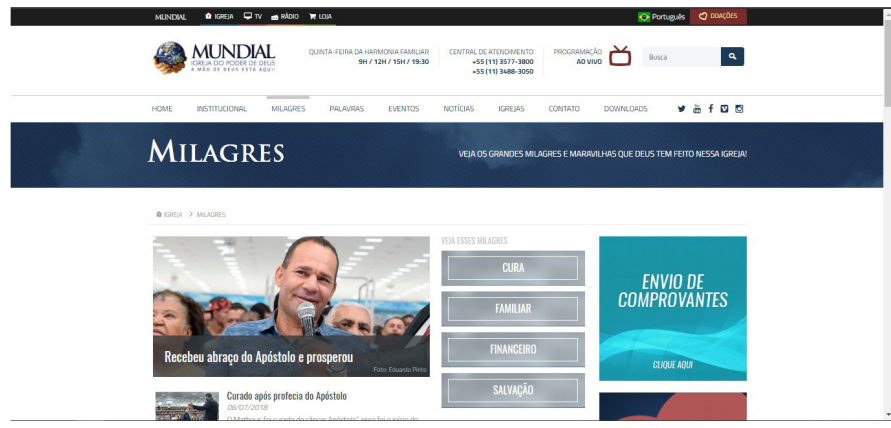

Imagem 1. Captura de tela da página do site Fonte: https://www.impd.org.br/milagres.

O site se constitui como uma prática intersemiótica (MAINGUENEAU, 2008), pois ele se organiza por marcas linguístico-enunciativas e imagéticas. O plano de fundo evoca uma série de informações acerca da igreja, desde a história da fundação, as principais doutrinas, os horários dos cultos, a localização dos templos mais próximos e dados bancários destinados a ofertas e pagamento de dízimos on-line, tudo em versão em português, espanhol e inglês. Na aba superior da página principal, abaixo da logomarca da IMPD, há, na parte superior em uma faixa azul com letras brancas, em caixa alta, à esquerda, os tópicos de acesso, dentre eles, "Milagres" e, mais do centro para a direita, o enunciado Veja os grandes milagres e maravilhas que Deus tem feito nessa igreja!

O acesso ao tópico "Milagres" leva-nos à parte do site voltado para a divulgação dos discursos testemunhais, proferidos durante 
o ritual em diferentes templos. Tais discursos, após o culto, passam por procedimentos de edição e de retextualização por uma equipe da igreja, que acrescenta a imagem do fiel, o espaço e as circunstâncias da enunciação, antes de postá-lo definitivamente no site. Neste mesmo tópico, no canto esquerdo, já é possível entrar em contato com alguns discursos testemunhais. No centro, há também quatro subtópicos temáticos dispostos e ordenados, indiciadores de percursos de organização e construção da ordem humana, demonstrando uma cosmologia constitutiva do universo institucional, que deve ser continuamente revisitado para a sua perpetuação. Esses subtópicos funcionam também como estratégias enunciativo-discursivas, reveladores dos fundamentos doutrinal-teológicos da IMPD: "Cura", "Familiar", "Financeiro" e "Salvação". Ainda que possamos dizer que esses itens lexicais carreguem marcas teológicas e definem um percurso para a IMPD, elas envolvem estruturas atitudinais em seus aspectos interacionais e discursivos e, acima de tudo, definem as dimensões e valores ético-religiosos da Teologia Neopentecostal.

A "cura" é a base para a salvação, na medida em que propicia a recuperação simbólica da saúde, da prosperidade e da relação com a salvação, o que confere ao sujeito religioso nova identidade. Nesta perspectiva, a cura se alcança por meio da fé e, assim, ela se torna um trampolim para a salvação da alma, pois a doença é uma manifestação de malefícios do corpo, portanto, precisa dos benefícios e do milagre da cura. Para Campos (1997, p. 356), “curar é levar as pessoas à salvação, por meio de um afastamento radical das causas de seus males, o demônio. A cura é, nesse sentido, uma recuperação da harmonia e da paz (...)”.

A segunda dimensão é a "familiar" e visa a repensar que a salvação de cada fiel está condicionada à felicidade familiar. É, por isso que, pelo trajeto familiar, o fiel ganha prosperidade e atinge a 
salvação. A dimensão "financeiro" é seguida e associa-se não somente a um empreendido do fiel com a instituição, mas também estabelece-se como um processo de confirmação na fé, uma vez que a própria IMPD supõe seu financeiro em consonância com o fiel. Isto advém e resulta da/na Teologia da Prosperidade que enfatiza o financeiro, a riqueza e o poder, de forma a prestigiar a saúde financeira do fiel aqui na terra, relacionando-o à vida celestial. Decorrente das dimensões anteriores está a "salvação", que se institui como consequência de uma trajetória de vida invocada pela Teologia da Prosperidade. Isso significa recorrer a uma concepção de vida entendida, a princípio, sob orientações institucionais subjacentes ao campo discursivo da IMPD. Com esse posicionamento, o site reforça a existência de uma identidade religiosa, apta a valorizar a vida terrena ao mesmo tempo em que mobiliza a vida extraterrena por meio da salvação.

No canto direito, com fundo azul, que nos remete à cor do céu, encontramos em caixa alta o enunciado ENVIO DE COMPROVANTES e, logo abaixo, no modo imperativo, clique aqui. Os dois enunciados estão separados por um azul harmonioso mais claro, em forma de um caminho, que estabelece uma ligação entre o humano e o divino. Os dois tons complementam-se e tornam mais fluida e menos tensa a relação entre os enunciados "Envio de comprovantes e o clique aqui" materializado em azul mais forte. Assim, fica evidente que esses enunciados são mais do que um pensamento, eles sinalizam um procedimento normativo institucional. Assim, fica perceptível ao fiel o apelo à doação como condição à salvação e ao alcance de Deus, no céu. 


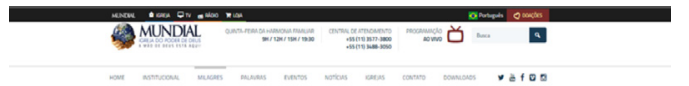

Milagres

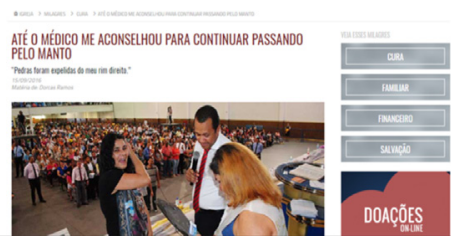

Imagem 2. Captura de tela da página do testemunho Fonte: https://www.impd.org.br/milagres/878

Para acessarmos o discurso testemunhal, objeto deste estudo, por abordar a cura de uma patologia renal, entramos no subtópico "cura". Ali encontramos, em vermelho, um enunciado destacado, sobreasseverado ATÉ O MÉDICO ME ACONSELHOU PARA CONTINUAR PASSANDO PELO MANTO, realçado a título do discurso que, de certa forma, resume a proposta doutrinal do discurso. Segundo Maingueneau (2014) esse tipo de destacamento impõe ao discurso um caráter normativo em tom solene. $\mathrm{O}$ emprego do item lexical "até" elucida-nos claramente o fato da inclusão de algo tido como inesperado, ou seja, o campo da ciência é subvertido pelo campo da religiosidade, fé. Logo abaixo do título, apreendemos o enunciado "Pedras foram expelidas do meu rim direito", enunciado já-dito, aforizado, um discurso em estilo direto, reproduzindo a fala autêntica do enunciador. Ele também possui uma grafia diferenciada, ou seja, está em negrito e com aspas, demarcando uma forte responsabilidade do sujeito que enuncia, mas assumida pela IMPD que a toma como fonte de convicção. Podemos dizer que não houve transformação do enunciado, de forma a resumi-lo, tendo sido destacado do discurso ritualizado, e aqui foi colocado logo após o título, pois comunica e evento da cura. Tal organização discursiva não fora feita de modo aleatório, na medi- 
da em que visa a complementar as informações contidas no título e no funcionamento do discurso, como um dado de marketing motivador dos fieis e daqueles que querem conhecer a IMPD.

Do ponto de vista gramatical, podemos observar que a estrutura sintática do enunciado "pedras foram expelidas do meu rim direito" está na passiva, topicaliza pedras e apaga o agente, produzindo um efeito de sentido em que Deus, o sujeito- autor da ação silenciou-se para dar voz à IMPD, que tem poder de administrar o acordo da negociação dos efeitos de sentido desejados para aquele enunciado. Logo abaixo dos enunciados analisados anteriormente, estão a data do momento em que o discurso foi enunciado e a indicação do nome do jornalista Dorcas Ramos, responsável pela edição da matéria, Podemos notar também que a série nominal cura, família, financeiro e salvação está no canto superior direito, e logo abaixo, em fundo azul, um coração em vermelho, com a palavra DOAÇÕES, na cor branca, em caixa alta e, abaixo, ainda dentro do coração, a expressão on-line, como uma espécie de profissão de fé que possibilita a quem realizar esse apelo um engajamento pleno na IMPD. 


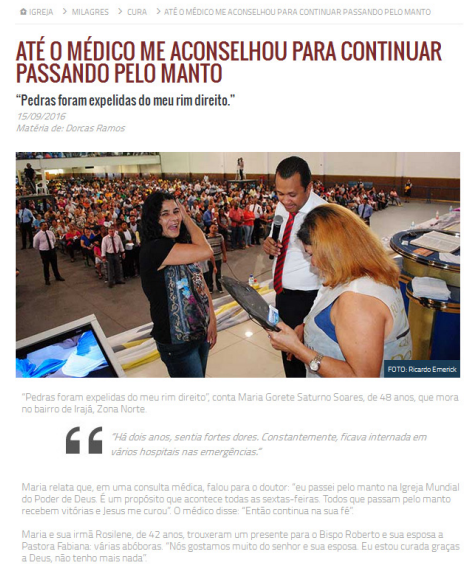

Imagem 3. Captura de tela da página do testemunho de modo ampliado Fonte: https://www.impd.org.br/milagres/878

O discurso testemunhal que selecionamos passou do espaço do ritual para o da mídia. É uma mudança crucial a passagem de um espaço discursivo a outro, pois muda a estrutura e o funcionamento do discurso e gera novos efeitos de sentido. Procurando articular Religião e mídia à IMPD por meio de um sistema restrições semânticas comuns, nossa análise se concentrará exclusivamente sobre o discurso testemunhal postado no site da instituição. Apreendemos da cenografia desse discurso, que ela produz a encenação do tema da cura, onde Deus opera milagre, mediado pelo contato com o manto sagrado, em um templo da IMPD, localizado no Rio de Janeiro.

Ao defrontarmo-nos com o discurso testemunhal, em análise, imediatamente observamos uma cenografia, que nos remete a uma cena englobante que impõe a este discurso uma tipologia da religiosidade. Embora sejam importantes as cenas englobante e genérica, restringimo-nos aqui à cenografia que, em primeiro plano, no altar, apresenta o Bispo Roberto, no instante em que Maria Gorete Saturno Soares de 48 anos enuncia um discurso ao lado de 
sua irmã Rosilene de 42 anos. Em um plano de fundo, os obreiros e uma multidão de fiéis, em meio ao colorido das vestes pessoais e a ambiência eclesial constituem uma cenografia leve e reflexiva. À esquerda do altar, vemos um monitor com as cores celestiais e ao fundo da Igreja, observamos, à esquerda, um cinegrafista, gravando a cena e, à direita, mais fiéis em um mezanino. Ressaltamos que há uma adequação entre as imagens que organizam a cenografia e o material linguístico, uma vez que os enunciados conferem um estatuto de religiosidade ao discurso.

\section{Recorte 1}

\section{"Pedras foram expelidas do meu rim direito."}

Neste recorte, o enunciador enuncia pelo espaço discursivo da cura a ocorrência de um milagre pela expulsão de pedras de seu rim. As aspas mostram que ele se responsabiliza pelo que ele enuncia e valida pela convicção pessoal baseada em uma experiência vida realmente. Neste sentido, o discurso reatualiza, por meio de estilo direto, por um enunciado aforizado, outro espaço discursivo, o do ritual, estabelecendo entre esses espaços uma relação indissociável. Por circular no ritual e na mídia, no contexto do posicionamento da IMPD e, por conseguinte, em mesma formação discursiva, esse enunciado produz diferentes efeitos de sentido, a partir de sua circulação. A postura do enunciador de utilizar um código linguageiro do campo discursivo da medicina - expelir pedras - mostra que ele se assume como responsável por sua própria enunciação, ao mesmo tempo em que sacraliza o caráter mágico e irracional da cura. Essa reflexão é perfeitamente significativa, pois a remoção das pedras no rim direito não se deveu a uma intervenção cirúrgica, mas pelo poder do manto sagrado da IMPD. 


\section{Recorte 2}

Há dois anos sentia fortes dores. Constantemente ficava internada em vários hospitais nas emergências.

Por meio do recorte 2 , podemos verificar que a coerência semântica do discurso precisa confirmar o evento enunciativo enunciado no recorte 1 , de modo a garantir sua ocorrência, sem contestá-lo. Parece-nos pertinente esclarecer que a cura pela expulsão das pedras do rim, um evento milagroso, vem confirmar a pertinência da doença, sua gravidade (dores fortes, internação constantes) e o desejo de cura pelas visitas contínuas a vários hospitais, razões que o enunciado do recorte anterior não mencionou, ao se constituir na cenografia. É importante considerar, ainda, a ausência de aspas neste enunciado e considerarmos seu alcance, pois que esse apagamento torna-se aqui um novo critério legitimador do milagre ocorrido, dando sustentação ao enunciado incontestável do recorte anterior.

\section{Recorte 3}

Maria relata que, em uma consulta médica, falou para o doutor: "eu passei pelo manto na Igreja Mundial do Poder de Deus. É um propósito que acontece todas as sextas-feiras. Todos que passam pelo manto recebem vitórias e Jesus me curou". O médico disse: "Então continua na sua fé". 
No recorte 3, a cenografia se instala como um relato em que o enunciador, durante uma consulta médica, explica ao médico ter passado pelo manto da IMPD. Trata-se de um tecido de aproximadamente 24 metros, com 5 de largura, e consagrado no monte São Roque, interior de São Paulo. Todavia, a sua principal característica é que, quem atravessá-lo, tem o mal extinto. $\mathrm{O}$ enunciado relata, ainda, que a possibilidade de passar pelo manto acontece às sextas-feiras e que todos que passam por ele recebem vitória. Por fim, sintetiza com o enunciado Jesus me curou. Uma assertiva inquestionável. O médico contra-argumenta, ao enunciar "Então continua na sua fé". Este recorte nos mostra que a magia da cura e a consulta médica são práticas sociodiscursivas que se opõem. O enunciador, pela evocação do ato de linguagem do médico, assume a posição de que ele está consciente da limitação de seu poder e que as forças espirituais o suplanta. Ressaltamos, ainda, que a compreensão do enunciador "Jesus me curou" exige que consideremos o enunciado proferido pelo médico "Então continue na sua fé" no processo de comprovação da cura, do milagre. Trata-se de uma determinação em que o médico, convertido em aforizador, formula um procedimento comportamental como proposta de atitude adequada às normas da IMPD, embora ele como especialista em medicina não possa assumi-lo. Por isso, tanto o enunciador quanto o médico demarcam seus posicionamentos e validam seus enunciados. O fato de o médico aconselhá-la a continuar passando pelo manto reforça a permanência dela no ritual e na IMPD.

De fato, observamos, no funcionamento discursivo, que o interdiscurso se faz presente por meio de uma tensão entre campos discursivos distintos, ou seja, cada um de campos discursivos diferentes, o da religiosidade, cuja FD é a neopentecostal, e o da cientificidade, cuja FD é o da medicina. Entretanto, no discurso em análise, o primeiro ressignifica o segundo, a partir do seu próprio posicionamento. 


\section{Recorte 4}

Maria e sua irmã Rosilene, de 42 anos, trouxeram um presente para o Bispo Roberto e sua esposa a Pastora Fabiana: várias abóboras. "Nós gostamos muito do senhor e de sua esposa. Eu estou curada graças a Deus, não tenho mais nada".

Neste recorte 4, o enunciador, atribuindo o item lexical irmã, a Rosilene de 42 anos, busca referenciar a vida em família, fortalecendo os laços de união da IMPD e estendendo essa referência ao Bispo Roberto e sua esposa, Pastora Fabiana, pelo presente ofertado como forma de união fraterna frente à bênção que recebeu. O enunciado "Nós gostamos muito do senhor e de sua esposa" não se limita apenas a eles, mas se estende a toda a IMPD, a qual, por meio dela, irmanados em família, chega-se a Deus. Ademais, segundo o enunciado "Eu estou curada graças a Deus, não tenho mais nada" significa que o milagre aconteceu, a cura ocorreu e não pelos médicos. Logo, o efeito de sentido produzido é de que a IMPD é o poder de Deus. É nela e por ela que os milagres acontecem e são comprovados pelos discursos testemunhais de seus fieis e ratificados pela instituição.

\section{Considerações finais}

No decorrer deste capítulo, buscamos empreender um exame do discurso religioso testemunhal produzido na Igreja Mundial do Poder de Deus e disponibilizado no site na instituição. Nosso percurso considerou as condições sócio-históricas de produção do corpus que selecionamos, avaliando-as essenciais à inteligibilidade 
do discurso, na medida em que esse lugar teórico-metodológico deu-nos um caminho para a análise que fizemos. Para isso, revisitamos questões relacionadas ao Neopentecostalismo e à maneira como esse posicionamento incide sobre a IMPD, fundamentando seu estatuto ético-religioso. A contribuição de Hervieu-Léger, da Sociologia da Religião, com sua ideia de modernidade religiosa, funcionou como uma alternativa teórica para a compreensão da maneira como a IMPD, na atualidade, opera com a religiosidade na mídia.

Nossa análise se fundamentou na $\mathrm{AD}$, na perspectiva enunciativo-discursiva proposta por Maingueneau, cujo caráter interdisciplinar permitiu-nos dialogar com a Religião e a mídia, ambas como um lugar-social de representação e legitimação de valores ético-religiosos. Pudemos depreender que os discursos testemunhais são destinados a revelar poderes e que a dialogicidade da produção e circulação desses discursos estão relacionadas e adequadas às orientações e dizeres de como a IMPD determina e investe na condução da vida humana.

A problematização desenvolvida ao longo deste capítulo visou a contribuir com as interfaces que a Linguística, particularmente, a $\mathrm{AD}$ propõe realizar com a Religião e a mídia no espaço acadêmico. De um lado, os estudos sobre a religiosidade devem alçar novos voos, deixar de olhar o texto como materialização de uma verdade única e com significado transcendental. De outro, a $\mathrm{AD}$ precisa investir e ampliar seu universo discursivo para além de práticas sociais estritamente linguísticas, integrando em seus procedimentos analíticos a domínios intersemióticos.

Por fim, considerando as perspectivas da $\mathrm{AD}$, os estudos de Maingueneau e a análise que empreendemos sobre o discurso testemunhal de cura, uma das práticas teológicas da IMPD na mídia, podemos dizer que aquilo que faz o ser humano se manifestar 
na atividade religiosa, por meio do discurso e da manifestação do milagre, leva-nos a compreender a legitimidade e a credibilidade da ação, quando discursivizada e publicizada na mídia. De fato, a mídia está dando uma nova configuração à Religião, inclusive, fazendo com que os fieis estendam o espaço do templo para outros espaços de convivência mediatizados pelo site, por exemplo. Com certeza, eles estão cada vez mais envolvidos pela mídia, ou seja, midiatizando a fé. Cumpre-nos dizer, ainda, que, no processo de exame do discurso religioso, o analista do discurso deve considerar as condições sócio-históricas de produção do discurso, a relação ritual versus mídia, a ocorrência da interdiscursividade na memória e os lugares-sociais de onde os sujeitos interagem com outros sujeitos para negociarem efeitos de sentido.

\section{Referências}

ALTHUSSER, Louis. Ideologia e aparelhos ideológicos do Estado. Lisboa: Presença, s/d.

BARBOSA, Aron Édson Nogueira Giffoni. Aspectos do Neopentecostalismo na Igreja Mundial do Poder de Deus. Disponível em:http://www.uff.br/graduacaocienciassociais/files/2010/11. Acesso em 15/07/2018.

BARROSO, Victor B.F. Modernidade religiosa: memória, transmissão e emoção no pensamento de Danièle Hervieu-Léger. São Paulo: Fonte, 2014.

CAMPOS, Leonildo Silveira. Teatro, templo e mercado. Organização e marketing de um empreendimento neopentecostal. Petrópolis: Vozes, 1997.

ELIADE, Mircea. Mito e realidade. São Paulo: Perspectiva, 1972.

FEITOSA, Carla Valéria da Costa. Religião e mídia: comunicação 
e poder. In: Tuiuti: Ciência e Cultura, n. 46, p. 205-214, Curitiba, 2013. Disponível em http://www.utp.br/tuiuticienciaecultura/ ciclo_4/tcc_46_programas/pdf_46/art13_religiao.pdf. Acesso em 26/05/2018.

FRESTON, Paul. Evangélicos na política brasileira: história ambígua e desafio ético. Curitiba: Encontrão, 1994.

HASSMAN, Hugo. A Igreja eletrônica e seu impacto na América Latina. Petrópolis: Vozes, 1986.

HERVIEU-LÉGER, Danièle. O peregrino e o convertido: a religião em movimento. Tradução de João Batista Kreuch. Petrópolis, Rio de Janeiro: Vozes, 2008.

GADAMER, H.G. Verdade e método: traços fundamentais de uma hermenêutica filosófica. 12a ed., Petrópolis: Vozes, 2012.

JUNG, C.G. Memórias, sonhos, reflexões. Rio de Janeiro: Nova Fronteira, 1961.

MAINGUENEAU, Dominique. Novas tendências em análise do discurso. Campinas: Pontes/Unicamp, 1997.

. Cenas da enunciação. São Paulo: Parábola, 2008a.

. Gênese do Discurso. São Paulo: Parábola, 2008b.

. Doze conceitos em análise do discurso. São Paulo: Parábola, 2010 .

- Aforização, enquadramento interpretativo e configuração humanista. Trad. de Adriane Ribeiro Andaló Tenuta, Jean Cristtus Portela e Matheus Nogueira Schwartzmann. In: Coleção Mestrado em Linguística, Franca, v. 6, p. 15-34, 2011.

. Análise de Textos de Comunicação. Trad. Cecília P. de Souza-e-Silva, Décio Rocha, São Paulo: Cortez, 2013. . Frases sem texto. São Paulo: Parábola, 2014.

MARIANO, Ricardo. Os neopentecostais e a teologia da prosperidade. In: Novos Estudos CEBRAP, n. ${ }^{\circ} 44$, março 1996 p. 24-44 http:// 
novosestudos.org.br/v1/files/uploads/contents/78/20080626_os_ neopentecostais.pdf.Acesso em 15/07/2018.

- Mudanças no campo religioso brasileiro no censo 2010. In: Debates do NER. Porto Alegre, ano 14, n. 24, p. 119-137, 2013. Disponível em: http://sociologia.fflch.usp.br/sites/sociologia.fflch. usp.br/files/Campo\%20religioso\%20no\%20Censo\%202010.pdf. Acesso em 15/07/2018.

MARANHÃO FILHO, Eduardo M. (org.). Religiões e religiosidades no (do) ciberespaço. São Paulo: Fonte, 2013.

MARIZ, C.L. et. al. Pentecostalismo, Renovação Carismática Católica e Comunidades Eclesiais de Base - Uma análise comparada. Caderno CERIS, Ano I, nº 02, outubro de 2001.

NUNES, T.D. O crescimento das igrejas neopentecostais no Brasil: um olhar sobre a política da Igreja Universal. Cadernos de Pesquisas do CDHIS, número 35, ano 19, p. 127-132, 2006.

ORLANDI, Eni Puccinelli. Interpretação. Petrópolis: Vozes, 1996.

. A linguagem e seu funcionamento: as formas do silêncio. Campinas: Pontes, 2001.

SANTAELLA, Lúcia. SANTAELLA, Lúcia. Da cultura das mídias à cibercultura: o advento do pós-humano. Revista Famecos, n. 22. Porto Alegre, dez. 2003.

STOLOW, Jeremy (ed.). Deus in Machina. New York: Fordham University Press, 2012. 